\title{
Stress at Work and Its Subsequent Problems among Teachers of the Public Schools Which Operate the School-Based Violence Reduction Program (VRP) in Tulkarm Governorate
}

\author{
Rabee Oteer ${ }^{1, *}$ \\ ${ }^{1}$ Al-Quds University - Tulkarm branch \& Ministry of Education, Tulkarm, Palestine \\ *Correspondence: Al-Quds University - Tulkarm branch \& Ministry of Education, Tulkarm, Palestine. E-mail: \\ rabee_ateer@yahoo.com
}

Received: May 19, 2015

Accepted: June 6, 2015 Online Published: June 22, 2015

doi:10.5430/wje.v5n4p26

URL: http://dx.doi.org/10.5430/wje.v5n4p26

\begin{abstract}
This study aimed to identify the work-related stress and its subsequent problems among teachers of the public schools which operated the school-based Violence Reduction Program (VRP) in the governorate of Tulkarm during the second semester of 2015-2016. Besides, it aimed to identify the effect of specific variables, such as gender, specialization, qualifications and years of service, on the assessment process of stress at work and its subsequent problems. The study tool was a purposefully designed questionnaire, which consisted of 50 items. The validity and internal consistency of this measurement instrument were assessed, where the reliability coefficient score was 0.91 . The sample consisted of 130 teachers from public schools in Tulkarm area, which represented almost $100 \%$ of the study population. The results showed that there were inadequate criteria for teacher professional development, weak relationship between teaching faculty and school administration, lack of class discipline, prevalent problems among students, numerous teacher development workshops, lack of teacher decision-making participation, teacher involvement in undesirable activities, and heavy burden of teacher material obligations. They also showed that there were no statically significant differences in terms of the variables of gender, specialization, qualification, and work experience. The most important recommendations of the study included setting up a clear and particular strategy for developing educational evaluations, the development of educational work in line with technological developments, and employing self-evaluation methods.
\end{abstract}

Keywords: Work Pressure, Educational Supervision, Violence Reduction Program

\section{Introduction}

Work-related stress is one of the important, prevalent issues among the researchers in the modern educational sciences as well as the organizational behavior. The occupational stress is indeed one of the major problems incurred by public and private organization's staff, leading to institutional and entrepreneurial unproductive power and lower institutional quality and profitability.

Nearly all people experience some sort of stress. Human pressures and stresses lead to worry and anxiety, which have adverse effects on psychological and physical health both at home or in normal life. On the other hand, work-related stress is increasingly recognized as one of the most serious occupational health hazards, reducing workers' satisfaction and productivity and increasing absenteeism and turnover. (Al-Mishan, 2000: 206)

The work should be dealt within a narrower range of pressures. Job stress is an embedded part of work, besides members of staff are usually exposed to different levels of occupational stress, especially in the educational arena. The educators are often exposed to situations that exceed their responsibilities and abilities. (Mustafa, 2005: 290)

Many researchers argue that workers' reactions and their unwanted behavior, such as increased absenteeism and turnover, frequent complaints, increasing occupational faults, poor performance and other related forms of behavior, are caused by stress at work due to heavy workload and multiple relationships, which eventually lead to unbearable stress and burnout. Recent research has attempted to find solutions for the mental work-related issues in order to ensure smooth flow of work and prevent any unnecessary administrative problems, which probably arise from inadequate psychological surroundings. (Hayjan, 1998: 49) 
There is a major trend to addressing the work-related stress in educational institutions since teachers constitute the largest group of the teaching workforce. Indeed, the teacher is the most important element in the educational process and the cornerstone in the process of the professional development. He is directly responsible for the achievement of the educational targets, and he is the most influential person in his students' behaviors. (Talafhah, 2010). In addition, he plays other significant roles, including the development of leaders and workers in various fields and disciplines as well as the delivery of knowledge, education, and noble values in the minds of his students (Ahmad, 2006).

Teaching is the most important profession of all because it provides the society with the academically and socially, technically and morally qualified human resources. However, it is one of the most stressful jobs that leads to psychological and physical pressures because it is a very demanding job (Al-Shara \& Al-Baker, 2000).

The study of Forrest and Jepson (2006) shows that there are two main sources of work-related stress. It comes from the nature of the work environment and the workmates, including stress from the physical environment, as well as individual, social, and organizational factors. The second source constitutes the individual's intellectual and emotional features as well as his capacities and needs.

According to Gray and Starke, work-related stress is the combination of reactions that result from a combination of situations in the surroundings. They lead to a set of psychological and physiological variables on the individual. (Abdul Baqi, 2003: 330)

Likewise, Al-Abdali refers to seven major sources; six are internal, and one is external. These include work, role organization, stages of growth, environmental and climate regulations, internal relationships in the environmental regulations, higher regulations, and personality components. (Abdali, 2012: 37)

Many of the studies confirm the correlation between stress and performance where increasing stress levels lead to poorer performance. (Al-Kubaisi, 2003: 24)

Most business organizations tend to believe that stress at work has adverse effects on their performance. On the other hand, it has indeed some desirable effects. Kelly argues that it motivates the individual towards excellence and achievement of his objectives as he believes it constitutes the essence of his existence. (Al-Kubaisi, 2003:28)

\subsection{The Negative Effects of Job Stress are Divided into Many Types}

- The effects of stress at workplace: work-related stress has many implications, such as low levels of quality and productivity, accident-prone concentration, inconvenient working atmosphere, low morale, lack of job satisfaction, poor employee interrelations and unacceptable behaviour, higher turnover, lateness and absenteeism; and long-term illnesses. (Shbeir, 2009: 72)

- Psychological effects: job stress affects the employees' psychological status, often leading to depression, anxiety and occupational accidents. (Reggio, 1999: 290)

- Behavioral effects: increasing pressure at work often leads to bad habits such as smoking, weight loss, sleep disorder, hostility, and apparent lack of respect for institutional guidelines and regulations. (Al Emyan, 2004: 166)

The researcher concludes that the positive effects of stress at work are scarce compared with negative effects, which cause lower productivity, poor employee interrelations, along with poor socialization with family and friends and unhealthy relationships in the social contexts.

Therefore, the issue of stress work is very significant for the teachers in particular due to the Palestinian community's social, political and economic conditions, which have huge implications for the society as a whole. Besides, it leads to despondent circumstances for the members of the community who work in different domains.

Many studies have already attempted to assess the issue of stress at work. The study of Talafhah (2013) aimed to define the level of stress in the workplace among teachers who teach social studies in primary schools in Amman, Jordan, along with its consequential implications. Moreover, it aimed to determine the effect of the variables of gender, experience, and qualification on stress levels. The study sample consisted of 228 teachers from four directorates of education in Amman. The questionnaire included 52 items as well as an open question on the stress-caused problems. The results showed that the work-related stress was high in terms of the overall performance. There were significant differences attributed to the variable of gender in favor of male teachers and the variable of experience in favor of teachers with moderate experience (5-10 years). However, there were no significant differences in terms of the variable of qualification. The most common problem was the physical fatigue, and the least common problem was the sleep disorder. 
The study of Al-Hajaya (2012) aimed to find the occupational stress among secondary school headmasters and its effect on their creativity in Southern Jordan. The study sample consisted of 205 headmasters. The study found out that there were no statistically significant differences due to the variable of administrative experience in favor of administrative experience ( 5 years or less). There was a reciprocal relationship between work-related stress and headmasters' creativity. The study recommended that the Jordanian Ministry of Education should exert greater efforts towards occupational stressors to end them, since they have adverse impacts on headmasters' creative activities.

The study of Abu Rahma (2012) aimed to discuss the level of work-related stress and the level of the job satisfaction among the educational supervisors in the governorate of Gaza. The researcher used the analytical approach. The study sample included 189 supervisors from the Palestinian Ministry of Education and the UNRWA. The study tool, a questionnaire, consisted of two parts: stress at work (nine items) and job satisfaction (six items). The study found out that the level of work-related stress among the educational supervisors was moderate. There were no statistically significant differences in the arithmetic averages between the supervisors in terms of their attitudes towards stress at work due to the variables of gender and school type. However, there were significant differences due to the variables of gender, school type, work experience and educational directorate. The most important recommendation was that the Ministry of Education and the UNRAW agency should pay greater attention to work-related stress due to its adverse implications in the supervisors' overall performance.

Boyland's study (2011) aimed to figure the work-related stress among the primary school headmasters in the American Indiana State. It also aimed to examine the strategies used by those headmasters in coping with stress at workplaces. It endeavored to look at the significant differences in average averages among the study sample in terms of the variables of age, gender and work experience. The study sample consisted of 140 headmasters. The researcher used the descriptive, analytical method in the study, which used a questionnaire as a research tool. The study found out that the level of the work-related stress among the primary school headmasters was moderate. There were no statistically significant differences between the average means of the study sample in terms of the variables, and that school headmasters used effective ways to cope with mental burnout. The study recommended the need to use effective measures to help school administrators overcome burnout and strike balance between work and time.

The study of Shbeir (2009) aimed to identify the stress at work incurred by public school headmasters in the governorate of Gaza City, to pinpoint the differences in the average means of the views of the respondents in terms of the study variables, and to define the key ways to overcome occupational stress from their perspectives. The researcher used descriptive, analytical method; the study tool was a purposefully designed questionnaire; the sample included 364 headmasters in the governorate of Gaza. The study found out that the level of work-related stress among public school headmasters in the governorate of Gaza was moderate. There were differences in the occupational stress due to the variables of gender in favor of the headmistress; meanwhile, there were differences due to the variable of qualifications. The study recommended that the Ministry of Education in Gaza should assume greater attention to reduce the stress in schools and its effects on the teaching faculty, and to cut workload on the school administrators along with their ongoing rehabilitation.

The study of Glazer and Gyurak (2008) aimed to examine the concept of stress at work. The study sample included nurses from Hungary, Israel, Italy, Britain, and America. The question of the study was 'What is the main cause of stress and anxiety at your workplace?' The results showed that there were internal and external sources of stress. The most common sources of stress included the performance of certain tasks and the type of patients. The British nurses maintained that lack of professional skills was one of the major causes of job stress, whereas the Hungarian nurses believed that the two main stressors at workplaces were low salaries and lack of resources.

The study of Lazuras 2006 aimed to examine the occupational stressors and their adverse impacts on teachers in the private and public sectors in Greece. The study consisted of 70 teachers. The results showed that the main sources of stress at work were the personal conflicts, workload, and the regulations. The paper by Jeffrey and Trudy (2006) aimed at 'maximizing organizational leadership capacity for the future: Toward a model of self-leadership, innovation and creativity' in German industrial organizations. It mainly aimed to develop and present a model of self-leadership, innovation, and creativity. The paper presented theoretical and empirical evidence and a conceptual model of the relationships between self-leadership, innovation, creativity, and organizational support. The paper suggested that individuals with strong self-leadership considered themselves to have more innovation and creativity potential than individuals who had weak self-leadership, and that people who had innovation and creative potential would be more likely to practice innovation and creativity when they perceived strong support from the workplace than people who perceived weak support from the workplace.

The study by Miller and Travers (2005) investigated job stress, mental well-being, and job satisfaction among 
minority ethnic teachers in the UK. The study sample consisted of 208 teachers from the National Union of Teachers. The research indicated that this group of teachers suffered from poor mental health and a low-level job satisfaction due to four main sources of stress, including workload, cultural constraints, lack of status and promotion, and school type. The analysis in this report revealed that there were several factors that may have contributed to stress and dissatisfaction. It was found that this group of teachers faced ethnic discrimination. Other factors such as total stress, total self-esteem, working conditions, job satisfaction and total discrimination were major reasons for mental ill-health among minority ethnic teachers.

Boswell, et al (2004) studied the relationship between work-related stress and work outcomes. Their study found that feelings of challenge mediated the relation between challenge-related stress and work outcomes. The study hypothesized that two types of reported stress (challenge- and hindrance-related) have a divergent relationship with work outcomes (relating to desirable and undesirable outcomes, respectively) and a similar (positive) relationship with psychological strain. Results from a heterogeneous sample of university staff employees $(\mathrm{N}=461)$ supported many of the hypotheses. The two types of stress differently related to work outcomes yet both positively related to psychological strain. In addition, felt challenge mediated the relationship between challenge related stress and work outcomes, yet the effect of challenge related stress did not depend on job control.

The study of Khleifat and Zaghloul (2003) aimed to investigate the phenomenon of mental stress among a sample of 406 teachers in the Karak Governorate and its relation to some variables. The results indicated that the level of mental stress among teachers in the Karak Governorate was high. The results showed that the most common stressors were connected with the variables of income, local community, parents, extracurricular activities, school construction, school atmosphere and teaching process.

The study of Al-Omari (2003) examined the relationship between demographic and functional variables and job stress and its effect on the teachers in the public schools in Riyadh. The study sample included 472 teachers. The results showed that there was a negative moral relationship among the demographic variables, including age, salary, work experience and work stress. However, there was a positive relationship between functional variables of workload, role conflict, role ambiguity, job nature, job security and work stress. The functional variables were found to be more influential on job stress than demographic variables.

Goeller (1993) investigated the perception of the occupational stress and effective coping resources among Indiana female principals. The study sample consisted of 365 female principals. It revealed that there was a statistically significant perception among the female principals towards occupational stressors due to the variables of gender and age. However, there were significant differences in the occupational stressors due to the variable of school level in favor of secondary and middle school female principals.

\section{The Study Problem and Questions}

The researcher works as an educational advisor at the Palestinian Ministry of Education. During his close work with teachers, he noticed their dissatisfaction with heavy workload compared with available time, lack of resources and potentials, school surroundings, classroom sizes, lesson overload, teaching minor subjects that did not suit discipline, low salaries compared with higher cost of living. All these factors lead to confusion, unrest, frustration, physical and psychological burnout, and others. The teacher's personality had significant impacts on his behavior along with his professional performance in the class. His ineffectual performance was often attributed to his mental, social, professional conditions that often prevented him from acclimatizing with his work settings and getting on well with his students, leading to lower achievement and creativity.

The study problem was to investigate and reveal the level of work-related stress and its subsequent implications among the teachers of the public schools which operated the school-based Violence Reduction Program (VRP) in Tulkarm governorate. From the above-mentioned review, the study problem could be elucidated in the following key question:

What is the work-related stress incurred by the teachers of the public schools which operate the school-based Violence Reduction Program (VRP)?

The following sub-questions could be derived as follows:

1. Are there any significant differences in the respondents' perspectives towards work-related stress due to the study variables of gender, specialization, qualification, and work experience?

2. What are the levels of the stress implications for teachers who work in the public schools which operate the 
school-based Violence Reduction Program (VRP)?

\section{The Study Hypotheses}

This study aimed to examine the following zero hypotheses:

There are no significant differences at the level of significance of $(0.05(\leq)$ between the average means of the respondents' perspectives of the levels of job stress due to the variables of gender, specialization, qualifications and work experience.

\section{The Study Objectives}

- Defining the level of work-related stress among the teachers of the public schools which operated the school-based Violence Reduction Program (VRP)) in Tulkarm governorate.

- Defining the most important consequences of the work-related stress among the teachers of the public schools which operated the school-based Violence Reduction Program (VRP) in Tulkarm governorate.

- Defining the effect of the variables of gender, specialization, qualifications, and work experience on the level of job stress among the public school teachers which operated the school-based Violence Reduction Program (VRP).

- Delivering a set suggestions and recommendation in accordance with the study results.

\section{Significance of the Study}

- The teacher role is very fundamental for the success of the educational process.

- The adverse effects of the stress at work on the teachers' productivity, attitude and interactions with workmates. Thus, this paper examined this stress so as to find the appropriate means and procedures to reduce or resolve it.

- Teacher's rehabilitation should not be limited to periodical seminars and training sessions. It should rather include every physical and mental aspect. Hence, there is a need to maintain his performance in its best form so that he can perform duties and responsibilities and keep up with latest educational updates. Thus, this study sought to address stress at work and its implications. The study puts forward some expedient suggestions to save the teacher from stressful settings and burnout, which would lead to positive outcomes of his performance in the educational process.

\section{Limitations of the Study}

The study was limited to the teachers of some public schools which operated the Violence Reduction Program (VRP) in the Tulkarm governorate in the year 2014/2015 (Zenobia Basic Girls School, Al-Omariya Basic Girls School, Jamal Abdel Naser Secondary Girls School, Irtah Secondary Boys School, Ajnadeen Basic Boys School). Therefore, the study results were restricted to those boundaries, which were set by the researcher to address the issue of stress at schools that ran the Violence Reduction Program.

\section{Definitions of Terms}

Stress at work: unpleasant negative feeling that result from a heavy workload and work environment that affects or hamper the work environment (Shbeir, 2009: 9)

According to Luthans, job stress is an 'an adaptive response to an external situation that results in physical, psychological, and/or behavioral deviations for organizational participants'. (Luthans, 1992, 108)

According to the researcher, job stress is unfamiliar working circumstances incurred by the teacher during the teaching process. These unfriendly circumstances may exceed his abilities and thus his lead to depressing frustration, unbearable outcomes that probably cause physical and health ailments as well as psychological and social disorders. They were measured and assessed in this study through a purposefully prepared questionnaire.

Problems: any ensuing problems from the hindrance of the school workflow. (Ghanimat, 1995)

The researcher defines them as the job-related problems incurred by teachers during their work in schools. 


\section{Methodology and Procedures}

This descriptive research paper aimed to identify stress at work and its subsequent problems among the teachers of the public schools which operated the school-based Violence Reduction Program (VRP) in Tulkarm governorate.

\subsection{The Research Population}

The research sample consisted of 130 teachers (almost $100 \%$ of the study population) from the public schools which operated the school-based Violence Reduction Program (VRP) in the governorate of Tulkarm during the second semester of 2015/2016. The researcher used the systematic random sampling to determine the sample search. Table 1 shows the characteristics of the study sample.

Table 1. Characteristics of Study Sample

\begin{tabular}{|c|c|c|c|c|c|c|c|}
\hline Variable & Level & Number & Percentage & Variable & Level & Number & Percentage \\
\hline \multirow[b]{4}{*}{ Gender } & Male & 44 & 33.8 & 0 & Diploma & 11 & 8.5 \\
\hline & Female & 86 & 66.2 & 气ै & BA & 107 & 82.3 \\
\hline & Total & 130 & $\% 100$ & Ë & $\mathrm{MA}+$ & 12 & 9.2 \\
\hline & & & & : & Total & 130 & $\% 100$ \\
\hline \multirow{5}{*}{ Discipline } & Scientific & 51 & 39.2 & & $1-5$ & 17 & 12.11 \\
\hline & Academic & 79 & 60.8 & Work & $6-10$ & 36 & 27.7 \\
\hline & Total & 130 & $\% 100$ & experience & $11-15$ & 33 & 25.4 \\
\hline & & & & & $16+$ & 44 & 33.8 \\
\hline & & & & & Total & 130 & $\% 00$ \\
\hline
\end{tabular}

\subsection{The Research Instrument}

The researcher purposefully designed a research instrument to identify the stress at work and its subsequent problems. He investigated the previous educational literature and studies related to the subject of the study such as Shbeir (2009) study Talafhah (2013). The final form of study instrument consisted of two parts. The first one included some personal details about the respondents, including gender, discipline, qualification, and work experience. The second part included the survey itself, which consisted of 50 items.

The validity and internal consistency of this research instrument (questionnaire) was assessed by six competent arbitrators who lectured at the faculties of education in the Palestinian universities. The researcher omitted or modified some items in the questionnaire, which was initially made up of 55 items, and then five of them were removed. The final version of the questionnaire consisted of 50 items, following the agreement of more than $70 \%$ of the arbitrators. The Cronbach Alpha coefficient was used to find out the reliability of the instrument. The reliability coefficient of the total score was $(0.91)$, which was a high value.

\subsection{The Statistical Processing}

The researcher used the descriptive, statistical and analytical methodology. The descriptive statistical methods included the arithmetic averages, percentages and recurrence of the variables. The statistical analytical methods included the T-test and one-way ANOVA.

\subsection{The Results Analysis}

The aim of this research was to identify stress at work and its subsequent problems among the teachers of the public schools which operated the school-based Violence Reduction Program (VRP) in Tulkarm governorate. It also aimed to determine the impact of the variables of gender, discipline, qualifications, and work experience. The collected data were processed statistically using the Statistical Package for Social Sciences (SPSS).

\section{The Research Results}

The statistical analysis revealed the following results:

\section{First: Results related to the first question:}

What is stress at work incurred by the teachers of the public schools which operate the school-based Violence Reduction Program (VRP)?

To answer this question, the mean averages and percentages were calculated for each item and variable along with 
the total score of the questionnaire (Table 2).

To elaborate these findings, the stress incurred by the teachers of the public schools which operated the Violence Reduction Program (VRP) was defined through the respondents' arithmetic means. The five score rating scale was used for measurement $(1-5=4)$; the domain was then divided by the number of the group to determine the length of the group $(4 / 5=0.80)$; thus, the first group was $(1+0.80=1.80) ;(0.80)$ was then added to each group as follows (Abu Dalal, 2010):

1. The average means $(1-1.80)$ and the percentage (less than \%36) showed a very low score.

2. The average means $(1.81-2.60)$ and the percentage $(\% 36.1-\% 52)$ showed a low score.

3. The average means $(2.61-3.40)$ and the percentage $(\% 52.1-\% 68)$ showed a moderate score.

4. The average means $(3.41-4.20)$ and the percentage $(68.1-\% 84)$ showed a high score.

5. The average means $(4.21-5)$ and the percentage (more than \%84) showed a high score

Table 2. Average Means, Percentages, and Item Score

\begin{tabular}{|c|c|c|c|c|c|}
\hline $\begin{array}{c}\text { Serial } \\
\text { number }\end{array}$ & $\begin{array}{l}\text { Number } \\
\text { of items }\end{array}$ & Item/group & Avg. & $\%$ & Score \\
\hline One & Eight & I think that the teacher's promotion methods are inappropriate. & 360 & 72.00 & High \\
\hline Two & $\begin{array}{l}\text { Thirty } \\
\text { three }\end{array}$ & I'm annoyed by students' lack of responsibility. & 3.58 & 71.69 & High \\
\hline Three & Seven & I’m annoyed by students' lack of motivation. & 3.56 & 71.23 & High \\
\hline Four & Fourty six & I think that salary is not proportionate with the workload & 3.43 & 68.62 & High \\
\hline Five & Nine & I am not well qualified for computerized instruction. & 3.42 & 68.46 & High \\
\hline Six & $\begin{array}{l}\text { Forty } \\
\text { eight }\end{array}$ & I think my students ask too many questions. & 3.42 & 68.46 & High \\
\hline Seven & $\begin{array}{l}\text { Thirty } \\
\text { seven }\end{array}$ & I do not get on well with my work colleagues. & 3.38 & 67.69 & Average \\
\hline Eight & Thirty & I am incompetent for using technology in instruction. & 3.12 & 62.31 & Average \\
\hline Nine & Five & $\begin{array}{l}\text { I am worried about the consequences of the teacher's annual } \\
\text { performance evaluation. }\end{array}$ & 3.09 & 61.85 & Average \\
\hline Ten & Fify & $\begin{array}{l}\text { I suffer from the weak relationship between the administration } \\
\text { and teachers }\end{array}$ & 3.08 & 61.69 & Average \\
\hline Eleven & Thirteen & $\begin{array}{l}\text { I suffer from regular problems between the students in the } \\
\text { school. }\end{array}$ & 3.05 & 61.08 & Average \\
\hline Twelve & $\begin{array}{l}\text { Twenty } \\
\text { two }\end{array}$ & $\begin{array}{l}\text { I suffer from the lack of students' discipline in the classroom } \\
\text { and within the school. }\end{array}$ & 3.03 & 61.08 & Average \\
\hline Thirteen & Twelve & $\begin{array}{l}\text { I suffer from the weak relationship between the supervisors } \\
\text { and the teachers. }\end{array}$ & 3.02 & 60.62 & Average \\
\hline Fourteen & $\begin{array}{l}\text { Twenty } \\
\text { seven }\end{array}$ & $\begin{array}{l}\text { I suffer from the difficult application of the curriculum } \\
\text { activities. }\end{array}$ & 2.97 & 60.31 & Average \\
\hline Fifteen & $\begin{array}{l}\text { Twenty } \\
\text { five }\end{array}$ & $\begin{array}{l}\text { I suffer from recurrent changes and amendments in the } \\
\text { curricula. }\end{array}$ & 2.96 & 59.38 & Average \\
\hline Sixteen & $\begin{array}{l}\text { Twenty } \\
\text { eight }\end{array}$ & I think that the daily lesson plans are useless. & 2.92 & 59.23 & Average \\
\hline Seventeen & Three & $\begin{array}{l}\text { I think that the governorate-wide training sessions are } \\
\text { unproductive. }\end{array}$ & 2.92 & 58.31 & Average \\
\hline Eighteen & Six & $\begin{array}{l}\text { I think that the school administration disregards the teachers' } \\
\text { mental health status. }\end{array}$ & 2.89 & 58.31 & Average \\
\hline Nineteen & Forty two & $\begin{array}{l}\text { I dislike the inappropriate scheduling of teachers' training } \\
\text { courses. }\end{array}$ & 2.86 & 57.85 & Average \\
\hline Twenty & $\begin{array}{l}\text { Thirty } \\
\text { four }\end{array}$ & I have too many social duties. & 2.85 & 57.23 & Average \\
\hline Twenty one & Four & $\begin{array}{l}\text { I am dismayed because I do not participate in any } \\
\text { decision-making actions. }\end{array}$ & 2.77 & 57.08 & Average \\
\hline
\end{tabular}




\begin{tabular}{|c|c|c|c|c|c|}
\hline Twenty two & Fifteen & I am upset by the lack of educational facilities and potentials. & 2.75 & 55.38 & Average \\
\hline Twenty three & Twenty & $\begin{array}{l}\text { I think that the prescribed curricula are excessively hard and } \\
\text { condensed. }\end{array}$ & 2.66 & 54.92 & Average \\
\hline Twenty four & Forty & $\begin{array}{l}\text { I think that teacher's educational needs are not fulfilled } \\
\text { properly. }\end{array}$ & 2.62 & 53.23 & Average \\
\hline Twenty five & Fourteen & $\begin{array}{l}\text { I disapprove the teacher's involvement in undesirable } \\
\text { mandatory activities. }\end{array}$ & 2.61 & 52.46 & Average \\
\hline Twenty six & $\begin{array}{l}\text { Twenty } \\
\text { nine }\end{array}$ & I have a wave of financial commitments and expenses. & 2.59 & 52.15 & Average \\
\hline Twenty seven & Forty four & $\begin{array}{l}\text { I dislike and reject teaching material other than my } \\
\text { specialization. }\end{array}$ & 2.59 & 51.85 & Low \\
\hline Twenty eight & $\begin{array}{l}\text { Thirty } \\
\text { nine }\end{array}$ & $\begin{array}{l}\text { I am not competent enough to accomplish more than one task } \\
\text { at a time. }\end{array}$ & 2.57 & 51.85 & Low \\
\hline Twenty nine & $\begin{array}{l}\text { Thirty } \\
\text { five }\end{array}$ & I think that lesson weekly workload is unfair. & 2.56 & 51.38 & Low \\
\hline Thirty & $\begin{array}{l}\text { Thirty } \\
\text { two }\end{array}$ & As a teacher, I think I am not independent in my work. & 2.55 & 51.23 & Low \\
\hline Thirty one & Forty five & $\begin{array}{l}\text { I think that the school administration does not give proper } \\
\text { appreciation to teachers' achievements and efforts. }\end{array}$ & 2.51 & 51.08 & Low \\
\hline Thirty two & Sixteen & $\begin{array}{l}\text { I think that my work duties and requirements are not quite } \\
\text { apparent. }\end{array}$ & 2.48 & 50.15 & Low \\
\hline Thirty three & $\begin{array}{l}\text { Twenty } \\
\text { three }\end{array}$ & I think that daily school hours are long for teachers. & 2.43 & 49.54 & Low \\
\hline Thirty four & Thirty six & I dislike the large number of school exams. & 2.34 & 48.62 & Low \\
\hline Thirty five & One & $\begin{array}{l}\text { I think that teacher has few little powers and accountability } \\
\text { over his work }\end{array}$ & 2.29 & 46.77 & Low \\
\hline Thirty six & $\begin{array}{l}\text { Thirty } \\
\text { eight }\end{array}$ & $\begin{array}{l}\text { I think that the society has negative attitudes towards the } \\
\text { teaching as a profession. }\end{array}$ & 2.25 & 45.85 & Low \\
\hline Thirty seven & $\begin{array}{l}\text { Twenty } \\
\text { one }\end{array}$ & $\begin{array}{l}\text { I think that the teacher evaluation system is both futile and } \\
\text { inappropriate. }\end{array}$ & 2.25 & 45.08 & Low \\
\hline Thirty eight & Forty one & I think that teaching large classes is particularly challenging. & 2.15 & 44.92 & Low \\
\hline Thirty nine & Seventeen & $\begin{array}{l}\text { I think that most students do not complete their homework } \\
\text { assignments. }\end{array}$ & 2.14 & 43.08 & Low \\
\hline Forty & Nineteen & I have difficult burdens and obligations at home. & 2.12 & 42.77 & Low \\
\hline Forty one & $\begin{array}{l}\text { Twenty } \\
\text { for }\end{array}$ & I think that students lack respect towards teachers & 2.07 & 42.31 & Low \\
\hline Forty two & Eighteen & $\begin{array}{l}\text { I think there is no better good collaboration and cooperation } \\
\text { between teachers and parents. }\end{array}$ & 2.06 & 41.38 & Low \\
\hline Forty three & $\begin{array}{l}\text { Forty } \\
\text { nine }\end{array}$ & $\begin{array}{l}\text { I think that Students' weak academic performance is quite } \\
\text { challenging. }\end{array}$ & 2.06 & 41.23 & Low \\
\hline Forty four & $\begin{array}{l}\text { Thirty } \\
\text { one }\end{array}$ & $\begin{array}{l}\text { I think that teachers are overburdened with paperwork and that } \\
\text { their workload is unmanageable. }\end{array}$ & 1.99 & 41.23 & Low \\
\hline Forty five & $\begin{array}{l}\text { Forty } \\
\text { seven }\end{array}$ & I cannot cope with the increasing daily workload. & 1.88 & 39.85 & Low \\
\hline Forty six & Ten & $\begin{array}{l}\text { I suffer from emotional and physical exhaustion due to the } \\
\text { huge amount of work. }\end{array}$ & 1.78 & 37.54 & Low \\
\hline Forty seven & Two & I am dissatisfied and unhappy with my job as a teacher & 1.75 & 35.54 & $\begin{array}{l}\text { Very } \\
\text { low }\end{array}$ \\
\hline Forty eight & $\begin{array}{l}\text { Forty } \\
\text { three }\end{array}$ & $\begin{array}{l}\text { I think that my vocational development does not } \\
\text { commensurate with the nature of my work. }\end{array}$ & 1.62 & 35.08 & $\begin{array}{l}\text { Very } \\
\text { low }\end{array}$ \\
\hline Forty nine & $\begin{array}{l}\text { Twenty } \\
\text { six }\end{array}$ & I don't have a comfortable atmosphere at home. & 1.43 & 32.31 & $\begin{array}{l}\text { Very } \\
\text { low }\end{array}$ \\
\hline \multirow[t]{2}{*}{ Fifty } & $\begin{array}{c}\text { Twenty } \\
\text { two }\end{array}$ & Means of transport to/from school are quite difficult. & 3.03 & 28.62 & $\begin{array}{l}\text { Very } \\
\text { low }\end{array}$ \\
\hline & & Total score & 2.64 & 52.8 & Average \\
\hline
\end{tabular}


Table 2 shows that the score was high in items number $8,33,7,46,9$, and 48 . The percentage of the responses ranged between $68.1-84 \%$ of the items regarding the inadequacy of criteria and procedures for promotion, lack of personal responsibility among students, students' lack of motivation and interest, low salaries, and teachers' and educators' lack of the necessary skills for computerized educational material. The researcher believed that this was due to lack of promotion and transparency standards, the prevalence of favoritism and cronyism, lack of technological courses that supported modern educational technology in the teaching-learning process. The results of this study were consistent with the study of Miller and Traver (2005); here the score was average in the items 37, 30, $5,50,13,11,22,12,27,25,28,3,6,42,34,4,15,20,40$, and 14. The percentage of the responses ranged between $52.1 \%-68 \%$ in the items regarding weak relationship between teachers, lack of IT skills, weak relationship between headmasters and teachers, weak relationship between supervisors and teachers, anxiety of the implications of the annual performance evaluations, recurrent changes and amendments in the curricula, inappropriate scheduling of teachers' training courses, school administration disregards the teachers' mental health status, too many social duties, teacher's involvement in undesirable mandatory activities, and financial commitments and expenses. The researcher believed that this was due to the lack of objectivity in the teacher performance evaluation, lack of unified evaluation standards, poor relationship among supervisors, teacher, and headmasters, weak decision-making participation, planning teacher-training courses without involving them and assessing their desired training needs and setting proper schedules. The results of this study were consistent with the study of Talafhah (2013) and Lazarus (2006); the score was low in the items $29,44,39,35,32,45,16,23,36,1,38,21,41,17,19,24,18,49,31$, and 47 . The percentage of the responses ranged between $36.1 \%-52 \%$ in the items regarding teacher's work at school, weekly lesson plan, work requirements, teacher's delegated authority, physical factors classroom environment, student poor performance, and teacher's workload. According to the researcher, these issues were due to lack of the cooperation among various departments in the Directorate of Education in setting up appropriate programs and plans for the regulation of schoolwork. The score in the items 10, 2, 43, 26 was less than $36 \%$. The items were pertinent to job dissatisfaction, lack of proper professional training for the teaching practice, transportation problems, and lack of positive learning environment.

The total overall score was close to the mean or average (52.8\%). Such result was caused by the fact that teacher's coaching, mental, and social and other needs at the work level were not met due to the lack of lack of time, training, and material resources. These results were consistent with studies of Shbeir (2009) and Abu Rahma (2012).

\section{Second: Results related the second question:}

What are the resulting problems from the work-related stress incurred by the public schools teachers in Tulkarm district?

To answer the question, these were the most frequent concepts expressed by the teachers in the public schools which operated the school-based Violence Reduction in Tulkarm governorate:

* Mental health problems such as stress and anxiety.

* Job insecurity.

* Weak social relationships.

* Feeble teacher-teacher interpersonal relationships.

* Feeble student-teacher communication and synergy.

* Lack of Motivation and Commitment at work.

Third: Research Hypothesis:

There are no statistically significant differences at $(.05(\leq)$ in the level of work-related stress and its subsequent problems due to the variables of gender, specialization, qualifications, and teaching experience.

\subsection{Results Related to the Variable of Gender}

To test this hypothesis, an independent (unpaired) samples t-test was used to determine whether there were significant differences at $(\alpha=0.05)$ in the level of stress at work due to the variable of gender (table 2$)$. 
Table 3. Results of Independent Samples t-test of Job Stress by Gender

\begin{tabular}{cccccccc}
\hline & gender & number & average & SD & $\begin{array}{c}\text { degrees of } \\
\text { freedom }\end{array}$ & t-value & significance \\
\hline \multirow{3}{*}{ Total score } & male & 44 & 53.38 & 10.14 & & 0.97 \\
& female & 86 & 48.82 & 15.41 & 48 & 0.06 \\
\hline
\end{tabular}

* Statistically significant at the level of $(\alpha=0.05)$

Table (3) indicates the differences in the work-related stress and its subsequent problems due to the variable of gender were not significant in the overall score. This finding was inconsistent with the findings of the studies of Abu Rahma (2012) and Shbeir (2009). The researcher proposed that it was attributed to the work-related stress which was incurred by all teachers whether male or female since educational regulations apply to both boys and girls schools.

\subsection{Results Related to the Variable of Specialization}

1- To test this hypothesis, an independent (unpaired) samples t-test was used to determine whether there were significant differences at $(\alpha=0.05)$ in the level of stress at work due to the variable of specialization (table $3)$.

Table 4. Results of Independent Samples T-Test of Job Stress by Specialization

\begin{tabular}{cccccccc}
\hline & gender & number & Average & SD & $\begin{array}{c}\text { degrees } \text { of } \\
\text { freedom }\end{array}$ & t-value & significance \\
\hline \multirow{2}{*}{ Total score } & male & 51 & 53.99 & 12.70 & & 0.61 & 0.14 \\
& female & 79 & 52.06 & 9.49 & 0.48 & \\
\hline
\end{tabular}

Table (4) showed that the differences in the domain of job stress and its subsequent problems due to the variable of discipline were not significant in the overall score $(0.14$ was higher than 0.05$)$. The researcher proposed that it was attributed to the Ministry of Education Equal Pay Policy for both scientific and literary disciplines. In brief, the Discipline Standard required that all employees have the same salaries, the same lesson quotas, the same training courses and other issues.

\subsection{Results Related to the Variable of Qualification}

To test this hypothesis, a one-way ANOVA technique was used to determine whether there were significant differences at $(\alpha=0.05)$ in the level of stress at work and its subsequent problems due to the variable of educational qualification (table 5).

Table 5. ANOVA Summary of Job Stress by Educational Qualification

\begin{tabular}{|c|c|c|c|c|c|c|}
\hline & Source & SS & DF & MS & F-value & P-value \\
\hline & Between groups & 14.91 & 2 & 74.59 & & \\
\hline \multirow{2}{*}{ Total score } & Within groups & 55.76 & 47 & 11.8 & 0.62 & 0.53 \\
\hline & Total & 57.25 & 49 & & & \\
\hline
\end{tabular}

Note: *statistically significant difference at $(\alpha=0.05)$

Table (5) shows that the differences in the domain of job stress and its subsequent problems due to the variable of educational qualification were not significant in the overall score $(0.53$ was higher than 0.05$)$. This result was consistent with the study of Talafhah (2013). The researcher proposed that this was attributed to the Ministry of Education regulations that prevented high-qualified staff from career promotion and thus they remained equal to other colleagues in terms of job opportunities, work duties, professional development, annual salary increases and other privileges.

\subsection{Results Related to the Variable of Work Experience}

To test this hypothesis, a one-way ANOVA technique was used to determine whether there were significant differences at $(\alpha=0.05)$ in the level of stress at work and its subsequent problems due to the variable of work experience (table 6). 
Table 6. ANOVA Summary of Job Stress by Work Experience

\begin{tabular}{llccccc} 
& \multicolumn{1}{c}{ Source } & SS & DF & MS & F-value & P-value \\
& Between groups & 25.69 & 4 & 64.24 & & \\
\multirow{2}{*}{ Total score } & Within groups & 54.68 & 45 & 121.52 & 0.52 & 0.71 \\
& Total & 57.25 & 49 & & & \\
\hline
\end{tabular}

Table 6 shows that the differences in the domain of job stress and its subsequent problems due to the variable of work experience were not significant in the overall score $(0.71$ is higher than 0.05$)$. This result was inconsistent with the study of Al-Hajaya (2012). The researcher proposed that this was attributed to the Ministry of Education policies that regulated that all educators had equal job responsibilities and professional supervision irrespective of their years of teaching experience.

\section{Recommendations}

Based on the findings of the study and the theoretical framework and previous studies, the researcher recommends the following:

1. The development of clear, specific, and measurable criteria for Teacher Performance Standards and Evaluation, which takes into account the various aspects of the educational process.

2. The development of educational work in line with the recent technological developments and innovations.

3. The use of self-evaluation methodology and checklist.

4. The promotion of communication, partnership, and collaboration between principals, administrators, teachers, and parents.

5. The selection of the training courses and Professional Development Training based on in-service teachers' training needs surveys.

6. Identification and provision of the teacher's individual educational needs.

7. Maximizing the organization of conferences, seminars and lectures to review the recent changes in the educational policy.

8. The development of a research-based approach to detect relative strengths and weaknesses in the educational and evaluation aspects and the adequacy of teaching as a profession.

\section{References}

Abdul Baqi, Salah Al-Din. (2003). Principles of Organizational Behavior. University House, Alexandria, Egypt.

Abu Dalal, Husam. (2010). Trade unions and their role in the political development in Palestine. Unpublished MA thesis, Al-Azhar University, Gaza, Palestine.

Aburahma, Mohammed. (2012). Work stress and its relation with job satisfaction among supervisors in the Gaza Strip. MA thesis. Department of Education. Islamic University of Gaza.

Ahmad, Khaled Mohiuddin. (2006). Pressures of work and their relationship to job performance among teachers in public secondary and UNRWA schools in Jordan. Unpublished MA Thesis. Amman Arab University, Amman, Jordan.

Al-Abdali, Khaled. (2012). Mental toughness and its relationship to methods of coping with the psychological stress among a sample of secondary school high and ordinary achievers in Makkah. Unpublished MA Thesis. Umm Al-Qura University, Makkah.

Al-Emyan, Mahmoud. (2005). Organizational behavior in business organizations. Amman: Dar Wael Press \& Publishers.

Al-Hajaya, Suleiman. (2012). Labor Pressure and its Relation with Creative Behavior of Principals in Estate Secondary Schools in Southern Region of Jordan. Journal of Educational Psychology, 13(1), 305-324.

Alkubaisi, Muwafaq. (2003). How can Stress Affect Your Work Performance? Quantitative Field Study on Qatari Banking Sector. Business and Management Research Journal, 5(6), 24.

Al-Mashaan, Owaid. (2003). Studies on gender differences in job satisfaction. Kuwait: Dar Al Qalam Publishing \& 
Distribution.

Al-Omari, Obaid bin Abdullah. (2003). The pressures of work between teachers: a field study. Journal of the Faculty of Arts, 16(2), 12.

Boswell Wedy, Olson-Buchanan Julie \& Lepine Marcie. (2004). Relations between stress and work outcomes: The role of felt challenge, Job control, and psychological strain. Journal of Vocational Behavior, 6(4), 165-181.

Boyland, L. (2011). Job Stress Coping Strategies of Elementary Principals. Current Issues in Education, 14(3), 1-11.

Forrest, S., \& Jepson, E. (2006). Individual Contributory factors in Teacher stress on the role of Achievement Striving and Occupational. The British journal of Educational psychology, 76(2), 183-197.

Ghneimat, Mohamad Abdul Kader. (1995). Administrative and technical challenges facing head teachers in remote villages in Jordan. Unpublished MA thesis. The University of Jordan, Amman.

Glazer Sharon \& Gyurak Anett. (2008). Sources occupational stress among nurses in five countries. Intercultural Relations, 3(2), 49-66.

Goeller, T. (1993). Indiana female principals perceptions of occupational stress and effective coping resources. Dissertation Abstract International, 54(5), 1611

Hall A., Miller GV., \& Travers CJ. (2005). Ethnicity and the Experience of Work: job Stress and Satisfaction of Minority Ethnic Teachers in the UK. International Review of psychiatry, 7(5), 317-327.

Heijan, Abdul Rahman. (1998). Pressures of work: a comprehensive approach to study their sources, consequences and management. Institute of Public Administration: Riyadh.

Hussien S. Al-Sharaa \& Gamal M. Al-Bakir. (2000). Teachers Attitudes Toward teaching in Qatar and how could be affected by some Demographic Variables. Kuwait University. The Educational Journal, 14(56).

Jeffery, D., \& Trudy, C. (2006). Maximizing the organization of trust in supervisor and trust in an organization. Genetic Social and General Psychology Monographs, 2(126), 61-241.

Khleifat, Abdul-Fattah \& Imad Zaghloul. (2003). Sources of mental stress among teachers in the Karak Governorate and its relation to some variables. Journal of Educational Sciences, 18(3), 45-76.

Lazuras, Lambros. (2006). Occupational stress, negativity and physical health in and general education teacher in Greece. British journal of special education, $204-209$. http://dx.doi.org/10.1111/j.1467-8578.2006.00440.x

Luthans, F. (1992). Organizational behavior (2d ed.). New York: McGraw-Hill.

Mustafa, Abdul Azim. (2005). The stress at work and its relationship to career commitment in general secondary education. Journal of Future of Arab Education, 4(2), 277-352.

Riggio, Ronald. (1999). Introduction to Industrial/Organizational Psychology. Jordan: Dar El Shorouk for Publishing and Printing.

Shbeir, Mohamad. (2009). Pressures of work among public school principals in the governorates of Gaza and methods of dealing with them. Unpublished MA Thesis. Faculty of Education. The Islamic University, Gaza.

Talafha, Hamed. (2010). Social Studies Curricula and Their Methods of Teaching. Amman: Dar Al Maysara for Publication and Distribution.

Talafha, Hamid. (2013). Work Stress on Social Studies Teachers of Public Basic Schools in Jordan and its Resulting Problems. The Journal of the Islamic University for Educational and Psychological Studies, 21(1), $257-294$. 